\title{
Schwannoma parafaringeo: a propósito de un caso
}

\section{Secondary functional veloplasty: a non-obstructive approach to valopharyngeal insufficiency}

\author{
I. Doménech Juan', A. Monner Dieguez², E. Cisa Lluís³, A. Marí Roig³, B. de Frías', R. Jiménez
}

Resumen: Los Schwannomas del espacio parafaringeo son tumores muy infrecuentes, que se originan de la vaina de schawnn, generalmente de crecimiento lento, suelen ser asintomáticos. El tratamiento es quirurgico, muchas veces complejo por la localizacion anatomica

A continuación presentamos un caso de shawnnoma parafaringeo y una revisión de la literatura, debido al interés suscitado en nuestros servicios, por la escasa presentación de este tumor.

Palabras clave: Espacio parafaríngueo; Neurinoma; Schawannnoma.

\section{Introducción}

Los tumores del espacio parafaríngeo son raros, representan alrededor de un $0,5 \%$ de toda la patología oncológica de cabeza y cueIlo. Habitualmente son tumores que afectan a adultos, sin diferencias entre sexos y mayoritariamente son benignos. ${ }^{1}$

Los Schawnnomas son los segundos tumores en frecuencia de este espacio, aunque la mayoria de estos tumores se localizan en cabeza y cuello, los de localizacion extracraneal solo constituyen un $10 \%$ del total, de ahí su infrecuente presentación.

\section{Caso clínico}

Paciente mujer de 45 años derivada al servicio de Cirugía Maxilofacial por tumoración parotidea derecha de 6 meses de evolución,

\footnotetext{
1 Médico Residente del Servicio de Otorrinolaringología.

2 Jefe de Sección del Servicio de Cirugía Maxilofacial.

3 Médico Adjunto del Servicio de Cirugía Maxilofacial.

4 Jefe del Servicio de Otorrinolaringología.

Hospital Universitario de Belvitge. Barcelona.
}

\section{Correspondencia:}

Ivan Domenech Juan.

c/ Ibería no 11 3-2

08014 Barcelona

Abstract: The paraphararynx schawnnoma are very unusual tumours which are originated in the schwann sheath. They are usually asymptomatic and have a slow growth. Surgical treatment is required and its difficulty lies in the anatomical region.

Next we present a case of parapharynx schwannoma and a literature review due to the interest that it aroused in our service.

Keywords: Parapharyngeal space; Neurinoma; Schawnnoma.

\section{Introduction}

Tumors of the parapharyngeal space are a rare occurrence, representing around $0.5 \%$ of all of the oncological pathology relating to the head and neck. These tumors generally affect adults, they occur equally between the sexes, and the majority are benign. ${ }^{1}$

Schwannomas are the second most common tumor in this space. Although the majority of the tumors are located in the head and neck, those having an extracranial location account for only $10 \%$ of the total, hence their rare occurrence.

\section{Clinical case}

A female patient, aged 45, was referred to the Service of Maxillofacial Surgery with a 6-month history of tumefaction in the right parotid area. On exploration, a tumor was observed in the right parotid region, which was hard, painless and which also protruded at the oropharyngeal level, displacing the tonsils and the pharyngeal wall medially.

As a process of parapharyngeal expansion was suspected, a Computed Tomography (CT) scan was carried out which showed the expansion process within the parapha- 
clínicamente asintomática, a la exploración se aprecia tumoración en región parotidea derecha dura, indolora que protuye también a nivel orofaringeo desplazando la amígdala y la pared faringea medialmente.

Ante la sospecha de proceso expansivo parafaringeo se realiza un estudio de imagen mediante una Tomografía Computerizada (TC), donde se aprecia proceso expansivo parafaringeo, con escasa captación de contraste y componente quístico, sugestivo de tumor neurogénico, con extensión a la musculatura pterigoidea derecha que desplaza la luz orofaringea medialmente y la glándula parótida lateralmente (Figs. 1,2 y 3 ).

Una vez descartado un origen vascular, se realiza una PAAF que no resulta concluyente, por lo que se decide realizar una biopsia incisional por vía transoral, la cual es sugestiva de schwannoma.

Así pues ante el diagnóstico probable de neurinoma parafaringeo se decide realizar una exéresis por vía cérvico- parotidea, obteniendo una pieza quirúrgica de $5 \times 5^{\prime} 5 \times 3^{\prime} 5 \mathrm{~cm}$ encapsulada y de consistencia elástica que tras ser estudiada histológicamente se tipificó de schawnnoma del espacio parafaringeo.

\section{Discusión}

El espacio parafaringeo podemos entenderlo como una pirámide invertida con base en una pequeña porción del hueso temporal, próximo a la sutura petroesfenoidal y vértice en el asta mayor del hueso hioides, la pared medial está constituida por la fascia faringobasilar cranealmente y caudalmente por el músculo constrictor de la faringe, mientras que la pared lateral, la constituyen la fascia del músculo pterigoideo interno, lóbulo profundo de parótida y rama ascendente de maxilar inferior, anteriormente tene-

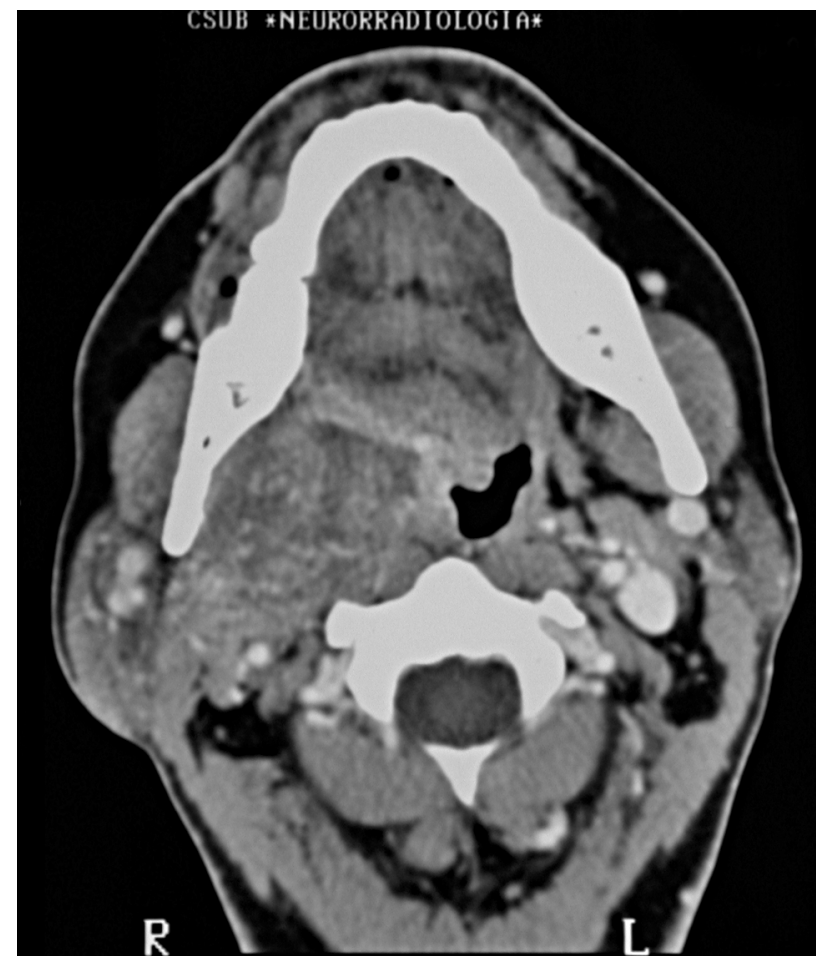

ryngeal space, with limited contrast and cystic component suggesting a neurogenic tumor extending to the pterygoid muscles on the right side which was displacing the light in the oropharynx medially and the parotid gland laterally. (Figs. 1,2,3).

Once a vascular source had been ruled out, a FNA was carried out which proved inconclusive, and a decision was made to perform a transoral incisional biopsy which suggested a schwannoma.

As the diagnosis was likely to be neurinoma of the parapharyngeal space, an excision using a cervicalparotid approach was decided upon, and a surgical specimen measuring $5 \times 5.5 \times 3.5 \mathrm{~cm}$ was obtained. It was encapsulated, of elastic consistency, and following histological examination proved to be a schwannoma of the parapharyngeal space.

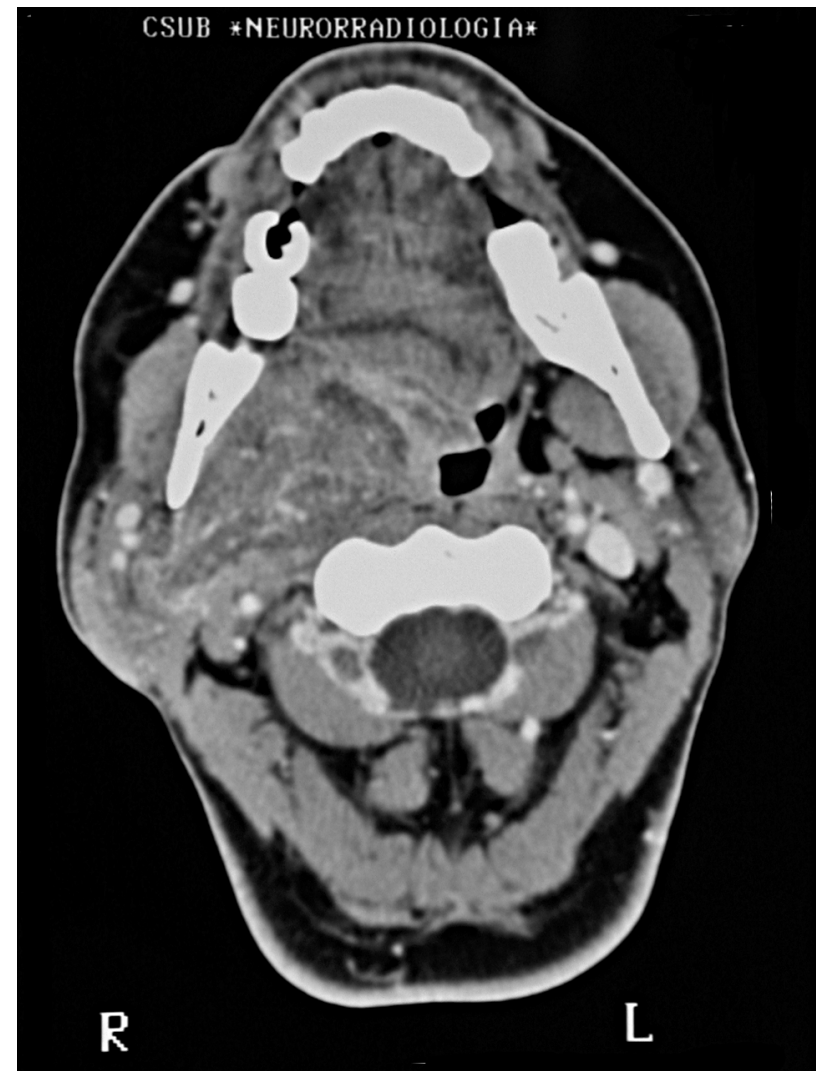

\section{Discussion}

The parapharyngeal space can be described as an inverted pyramid with its floor on the small portion of temporal bone near the petrosphenoid suture, and its tip at the greater horn of the hyoid bone. The medial wall is formed cranially by the pharyngobasilar fascia and caudally by the constrictor muscle of the pharynx, while the lateral wall is made up of the fascia of the internal pterygoid muscle, deep lobe of the parotid [gland] and ascending branch of the inferior maxilla. Anteriorly the limit is the pterygomandibular raphe and the medial pterygoid fascia, the posterior limit being the paravertebral muscles and prevertebral fascia. ${ }^{2}$ Within the parapharyngeal space there is the prestyloid compartment that contains fat and part of the deep lobe of the parotid [gland], and the retrostyloid [compartment] which contains the internal carotid artery, the internal jugular vein, cranial [nerve] pairs, and the cervical sympathetic [chain]. 
mos el rafe pterigomandibular y la fascia pterigoidea medial, y posteriormente los músculos paravertebrales y fascia prevertebral. ${ }^{2}$ Dentro del espacio parafaringeo distinguimos el compartimento preestileo ocupado por grasa y parte del lóbulo profundo de parotida y el retroestileo que contiene arteria carótida interna, vena yugular interna, pares craneales y el simpático cervical.

Así los tumores del espacio pre-estíleo serán lipomas y tumores glandulares y los retroestileos serán schwannomas y paragangliomas.

Los tumores salivares de la glándula parótida son los más frecuentes de esta región constituyendo aproximadamente un $50 \%$, seguido de los tumores neurogénicos que suman un 30\%, siendo el resto una miscelánea.

De los tumores neurogénicos los más frecuentes son los schwannomas o neurilemomas, seguidos por los quemodectomas y posteriormente por los neurofibromas. Aparecen a cualquier edad, la mayoría entre la $3^{\mathrm{a}}$ y $5^{\mathrm{a}}$ década, más frecuentes en el sexo femenino 3:1, originándose mayoritariamente del nervio vago, siendo el schwannoma del nervio vago el tumor más frecuente del espacio retroestileo, existiendo también de la cadena simpática cervical, del glosofaringeo, del hipogloso... etc.3,4 Existiendo incluso casos de pacientes con múltiples neurinomas de localización parafaríngeo, o bien asociados a neurinomas en otras localizaciones.5,6 La clínica más frecuente es la sensación de cuerpo extraño faringeo y el signo más frecuente, la protusión a nivel faringeo, por ser la zona de menor resistencia.7,8 Puede producir también disfagia, sensación de cuerpo extraño y voz de patata caliente, incluso si crece cranealmente, producir otitis serosa. Los síntomas derivados de compresión de estructuras nerviosas pares craneales IX, X, XI, XII, del simpático se verán en casos de neurinomas de gran tamaño, o bien en tumores malignos y quemodectomas. Dolor, trismus y lesiones de pares craneales sugieren malignidad.9,10

Él diagnostico se basará en la clínica, la exploración física, siendo importante la palpación bimanual, que permite reconocer la continuidad del tumor y determinar su origen.

Será de vital importancia el estudio radiológico mediante Tomografía Computerizada (TC) y Resonancia Magnética (RM) y en algunos casos completarlo mediante una angioradiología en casos de tumores hipervasculares. Al TC son tumores de densidad similar al músculo, más menos redondeados bien definidos con plano graso medial y lateral, como su origen más frecuente es el X par o la cadena simpática, suelen desplazar la arteria carótida interna anteromedialmente. La RM aporta una excelente informacion en el estudio de las partes blandas, siendo muy útil en este tipo de tumores y dicha región, son tumores hipointensos en T1 y hiperintensos en T2 y en T1 con gadolinio. ${ }^{4}$
The tumors in the prestyloid compartment will therefore be lipomas and glandular tumors and those of the retrostyloid [compartment] will be schwannomas and paragangliomas.

Salivary tumors of the parotid gland are the most frequent in this area and account for approximately $50 \%$ of tumors, after neurogenic tumors that account for around 30\%, the rest being miscellaneous.

The most frequent neurogenic tumors are the schwannomas or neurilemomas, followed by chemodectomas and then the neurofibromas. They appear at any age, mostly between the 3rd and 5th decade, but more frequently in females with a 3:1 ratio. The majority originate in the vagus nerve, and the schwannoma of the vagus nerve represents the most frequent tumor in the retrostyloid space. They also exist in the cervical sympathetic chain, the glossopharyngeal*[nerve], the hypoglossal [nerve] etc. ${ }^{3,4}$ There are also cases of patients with multiple neurinomas in the parapharyngeal area, or neurinomas associated with other areas. 5,6 The most frequent clinical [manifestation] is the sensation of a foreign body in the pharynx, and the most frequent sign is a protrusion at the pharyngeal level, as this is the area with least resistance.7,8 Dysphagia may also occur, sensation of a foreign body, and hot potato voice. Serous otitis may even occur if there is cranial expansion. The symptoms produced by the compression of the pairs of cranial nerves IX, X, XI, XII of the sympathetic [chain] appear in cases of large neurinomas, or in malignant tumors and chemodectomas. Pain, trismus and lesions in pairs of cranial [nerves] suggest malignancy. 9,10

The diagnosis depends on clinical [evaluation] and physical exploration. Bimanual palpation is important as it permits identifying the origin and continuity of the tumor.

Radiological studies by means of a Computed Tomography (CT) and Magnetic Resonance (MRI) is of vital importance, and should sometimes be backed-up with angioradiology in cases of hypervascular tumors. The tumors will appear on the CT scan to have a density similar to that of muscle. They have a more or less+ rounded contour, they are well defined, with a medial and lateral fat plane. As they commonly originate in the X pair [of nerves] or in the sympathetic chain, the internal carotid artery tends to be dis- 
El examen macroscópico suele corresponder a una tumoración de color blanca, amarillenta, bien delimitada de consistencia firme y elástica, en ocasiones con áreas quísticas. ${ }^{4}$

Desde el punto de vista microscópico existen dos grupos: Antoni A composición celular compacta en empalizada y Antoni B formado por una estructura laxa que se caracteriza por una degeneración mixoide, aunque la mayoría de las veces se presentan asociados. ${ }^{11}$

El tratamiento es quirúrgico, aunque debido a la infrecuente presentación de tumores en dicha localización es difícil la obtención de experiencia quirúrgica, existen diversas vías de abordaje, la cual estará en función del tamaño y la localización del tumor, siendo la más utilizada la vía cervical, 8,11 adecuada para la mayoría de tumores, en casos de mayor tamaño o bien para tumores de localización pre-estilea puede ser útil el abordaje cérvico-parotideo. ${ }^{12}$ En tumores de localización en lóbulo profundo de parótida puede realizarse un a vía transparotidea, reservando el acceso transmandibular en casos de tumores de gran tamaño o tumores malignos. La vía transoral se reserva para casos específicos por presentar riesgo de lesiones vasculares, exéresis parciales y riesgo de infección, no siendo muy apropiada para la mayoría de autores.8,12,13 Las complicaciones más fecuentes en la cirugía son la lesión del propio nervio y su deficit resultante, las recurrerencias son raras y suelen ser resultantes de una exéresis incompleta, teniendo en general un buen pronóstico postquirúrgico.

\section{Bibliografía}

1. Batsakis JG, Sneige N. Pathology consultation. Ann Otol Rhin ol Laryngol 1989;98:320-321.

2. Rouviêre H, Delmas A. Anatomía topográfica de la cabeza y cuello. Barcelona: Masson SA 1987;550-556.

3. Ganesan S, Harar R. Horner's sd: a rare presentation of cervical sympathetic chain schwannoma. The Journal of Laryngology and otology 1997;111:493-495.

4. Torossian J, Beziat J. Les schawnnomes exocriens de l'extremité céphalique. Annales de chirurgie Plastique Esthetique 1998;43(5):541-547.

5. Santoro R, De Meester W. Multiple neurinomas of the parapharyngeal space. Eur Arch Otorhinolaryngol 1997;254(6):301-3.

6. Michida A, Ryoke K. Multiple schawnnomas of the neck, mediastinum, and parapharyngeal space: repo of case. J Oral Maxilofac Surg 1995;53(3):617-20.

7. Mariño Espuelas J, De Vergas J. Schawnnomas parafaringeos. Acta Otorrinolaring Esp 1997;48(3):232-235.

8. Acosta L, Montalvao P. Tumores del espacio parafaringeo. Nuestra experiencia. Acta Otorrinolaring Esp 2002;53(7):485-490.

9. Maran AGD, Mackenzie IJ. The parapharyngeal space. / Laryngol Otol 1984;98:371380.

10. Carinci F, Carls FP. Schwannoma of the parapharyngeal space. J Craniofac Surg 2000;11(4):367-70.

11. Almela R, Cervantes JA. Schawnnoma de la cadena símpatica cervical. Anales O.R.L Iber-Amer 2002;39(1):37-46.

12. Olsen KD. Tumours and surgery of the parapharyngeal space. Laryngoscope 1994;104(63):1-28.

13. Carrau RL, Myers En. Management of tumours arising in the parapharyngeal space. Laryngoscope 1990;100:583-589. placed anteromedially. RMI provides excellent information regarding soft tissue, and it is very useful for these types of tumors and for this region. The tumors have a low signal intensity on $T 1$ and a high signal intensity on $T 2$ and on $T 1$ with gadolinium. ${ }^{4}$

Macroscopical examination tends to reveal whitish/yellowish tumor which is well defined with a firm, elastic consistency, and with cystic areas on occasions. ${ }^{4}$

From a microscopical point of view, there are two groups: Antoni $A$ with an elongated, densely packed cellular composition, and Antoni $B$ which is loosely structured with typical myxoid degeneration, although in most cases they appear together. ${ }^{11}$

Treatment is surgical, although due to the infrequent presentation of theses tumors in this area, gaining surgical experience is difficult. There are various methods of approach, which depend on tumor size and localization. The cervical approach is the most common, ${ }^{8,11}$ as it is adequate for most tumors. For larger tumors, or tumors of the prestyloid area, the cervical-parotid approach can be useful..$^{12}$ In tumors located in the deep lobe of the parotid [gland] a transparotid approach can be used, while the transmandibular approach should be reserved for large or malignant tumors. The transoral approach should be used only in specific cases as it carries the risk of vascular lesions, partial excision, infection, and for most authors it is not felt to be the most appropriate.8,12,13 Damage to the nerve itself, and the resulting deficit, is the most frequent complication in surgery. Recurrence is rare and is usually due to an incomplete excision and, in general, the postsurgical prognosis is good. 


\title{
Reconstrucción de cuero cabelludo con colgajo libre de omentum
}

\section{Reconstruction of the scalp with a free flap of omentum}

\author{
C. Navarro Cuellar1, F. Riba García' , B. Guerra Martínez², R. Pujol Romanya ${ }^{1}$, H. Herencia Nieto', \\ C. Navvarro Vila ${ }^{3}$
}

Resumen: Los defectos de cuero cabelludo pueden tener una etiología diversa. Resecciones oncológicas, lesiones postraumáticas e infecciosas pueden dar lugar a diferentes defectos en cuanto a tamaño y extensión. Para su reconstrucción disponemos de múltiples técnicas quirúrgicas como colgajos locales, regionales y expansores titulares. No obstante, para defectos extensos los colgajos libres son la única posibilidad reconstructiva. Presentamos el caso de un paciente con carcinomas epidermoides multicéntricos en cuero cabelludo tratado previamente con radioterapia en el que se realizó una resección amplia del cuero cabelludo y fue reconstruído con un colgajo libre de omentum.

Palabras clave: Cuero cabelludo; Colgajo libre de omentum.

\section{Introducción}

El cuero cabelludo es una zona ricamente vascularizada y constituída por múltiples capas descritas clásicamente con las siguientes siglas: SCALP(S, skin; $C$, subcutaneous tissue; $A$, aponeurosis o gálea; $L$, loose connective tissue; $P$, pericranium) ${ }^{1}$. Todas estas capas presentan una consistencia anatómica importante excepto a nivel de la región temporal donde encontramos la fascia temporoparietal que posteriormente se convierte en gálea en la línea temporal inferior y la fascia del músculo temporal con su músculo ubicados entre la gálea y el pericráneo.

\footnotetext{
1 Médico Residente

2 Médico Adjunto

3 Jefe de Servicio. Catedrático de Cirugía Maxilofacial

Servicio de Cirugía Maxilofacial

Hospital General Universitario Gregorio Marañón. Universidad Complutense, Madrid
}

Correspondencia:

Carlos Navarro Cuéllar

C/ María Molina $60,7^{\circ} \mathrm{A}$

28006 Madrid

E-mail: cnavarrocuellar@mixmail.com

\begin{abstract}
Scalp defects may have different etiologies. Oncologic resections, postraumatic lesions and infectious wounds may lead to a great variety of defects in size and extension. In order to accomplish the reconstruction we have different surgical techniques such as local and regional flaps and tissue expanders. Nevertheless, for more extensive defects free flaps are the only reconstructive possibility. We present the case of a patient with multicentric squamous cell carcinomas previously with radiotherapy. He underwent wide resection and was reconstructed with an omentum free flap.
\end{abstract}

Keywords: Scalp; Omentum free flap.

\section{Introduction}

The scalp is an area which is richly vascularized and which has classically been described with the following acronym: SCALP (S: skin; C subcutaneous tissue; A, aponeurosis or galea; $L$, loose connective tissue; $P$, pericranium) 1 . All these layers have an important anatomical consistency with the exception of the layer in the temporal region where we find the temporoparietal fascia, which then becomes galea by the inferior temporal line, and the fascia of the temporalis muscle with its muscle situated between the galea and the pericranium.

The scalp is relatively inelastic compared with the rest of the cervicofacial tissues. This is largely due to the fibrous union formed by the galea with the frontal muscle in front and the occipital muscle behind. ${ }^{1}$ Most scalp flaps as a consequence resist traction and transposition, and they often require more extensive designs for closing defects.

On the other hand, the scalp has the great advantage of its rich vascular supply. Irrigation to the scalp is done by five vascularized pedicles in each side, namely: the supratrochlear artery, the supraorbital artery, the superficial temporalis artery with its frontal and parietal branches, the pos- 